ORIGINAL ARTICLE

\title{
Topographical localisation of cagA positive and cagA negative Helicobacter pylori strains in the gastric mucosa; an in situ hybridisation study
}

\author{
M Camorlinga-Ponce, C Romo, G González-Valencia, O Muñoz, J Torres
}

J Clin Pathol 2004;57:822-828. doi: 10.1136/icp.2004.017087

See end of article for authors' affiliations

Correspondence to:

Dr J Torres, Prol. Av.

Centenario 1707-39.

México DF, CP 01580 ,

Mexico; jtorres|@axtel.net

Accepted for publication 17 March 2004

\begin{abstract}
Background: The cagA gene is a marker for the presence of the cag pathogenicity island, and the presence of cagA positive strains of Helicobacter pylori can identify individuals with a higher risk of developing gastrointestinal diseases.

Aims: To study the interaction between $\mathrm{H}$ pylori $\operatorname{cag} \mathrm{A}(+)$ and $\operatorname{cag} \mathrm{A}(-)$ strains and the gastric mucosa. Methods: Patients with $H$ pylori associated gastritis and peptic ulcers were studied. Biopsies were obtained from the antrum, corpus, fundus, and incisura for $\mathrm{H}$ pylori culture, and for in situ hybridisation studies. From each biopsy, multiple single $H$ pylori colonies were isolated and propagated for DNA isolation, and cagA was detected by the polymerase chain reaction (PCR). For in situ detection of $H$ pylori an oligonucleotide specific for an $\mathrm{H}$ pylori common antigen and an oligonucleotide specific for cagA were used as probes. Biotinylated probes were incubated with biopsy sections, developed with streptavidinhorseradish peroxidase, and amplified with the tyramide system.

Results: PCR results for cagA in isolated colonies confirmed the in situ hydridisation studies. In situ hybridisation identified $\operatorname{cag} \mathrm{A}(+)$ bacteria in patients with $\operatorname{cag} \mathrm{A}(+)$ isolates; $\operatorname{cag} \mathrm{A}(-)$ bacteria in patients with $\operatorname{cag} \mathrm{A}(-)$ isolates, and $\operatorname{cag} \mathrm{A}(+)$ and $\operatorname{cag} \mathrm{A}(-)$ bacteria in patients with both $\operatorname{cag} \mathrm{A}(+)$ and $\operatorname{cag} \mathrm{A}(-)$ isolates. $\operatorname{Cag} \mathrm{A}(-)$ bacteria usually colonised the mucous gel or the apical epithelial surface, whereas $\operatorname{cag} \mathrm{A}(+)$ bacteria colonised the immediate vicinity of epithelial cells or the intercellular spaces.

Conclusions: These results document a different in vivo interaction between $H$ pylori $\operatorname{cag} A(+) \operatorname{or} \operatorname{cag} A(-)$ strains and the gastric mucosa.
\end{abstract}

$T$ he organism Helicobacter pylori colonises the stomach mucosa of over $50 \%$ of the world's population; peptic ulcers develop in about $10-15 \%$ of these infected individuals and gastric carcinoma in less than $3 \%$ of patients. ${ }^{1}$ Differences exist in the genotypes of $H$ pylori strains, and the presence of vacA and of the cag pathogenicity island (cag $\mathrm{PAI}$ ) is linked to the development of peptic ulcers and gastric carcinoma. ${ }^{2-4}$ Infection with cag PAI $(+)$ strains is associated with increase interleukin 8 secretion by epithelial cells, which recruit inflammatory cells, ${ }^{5}$ and released interleukins may lead to cell damage, apoptosis, and DNA damage.

"The aim of our study was to develop an in situ hybridisation assay to differentiate between colonisation with Helicobacter pylori $\operatorname{cagA}(+)$ and $\operatorname{cagA}(-)$ strains in gastric biopsies"

The cagA gene is a marker for the presence of the cag PAI, and the detection of cagA positive strains may help to identify individuals with a higher risk of developing gastrointestinal diseases. Until now, the identification of infection with $\operatorname{cagA}(+)$ strains has been done by the isolation and culture of strains from biopsies and the detection of the gene by polymerase chain reaction (PCR) or hybridisation techniques. ${ }^{67}$ However, the in situ localisation of $\operatorname{cag} \mathrm{A}(+)$ and $(-)$ strains in the gastric mucosa has not been studied.

In situ hybridisation techniques using probes for specific genes allow the in situ identification of virulent versus nonvirulent infectious organisms and provide additional morphological information. The aim of our study was to develop an in situ hybridisation assay to differentiate between colonisation with $H$ pylori $\operatorname{cagA}(+)$ and $\operatorname{cagA}(-)$ strains in gastric biopsies.

\section{MATERIALS AND METHODS}

\section{Gastric biopsy specimens}

Gastric biopsies were obtained from patients attending the Hospital de Especialidades, IMSS in Mexico City. Patients infected with $H$ pylori, with non-ulcer dyspepsia, duodenal ulcer, or gastric ulcer were studied. From each patient, two biopsy specimens were obtained from the antrum, corpus, fundus, and incisura. From each region, one biopsy specimen was used for bacterial culture of $H$ pylori, whereas the second was fixed and embedded in paraffin wax and used for in situ hybridisation studies. As negative controls, biopsies from two patients with $H$ pylori negative gastritis were studied.

\section{Isolation of multiple single colonies of $\boldsymbol{H}$ pylori from biopsies}

Biopsies were inoculated on to blood agar plates with antibiotics. From the primary growth, seven to 10 single colonies were propagated on blood agar medium. The identity of the strains was confirmed by Gram stain, urease, oxidase, and catalase tests. Colonies were swept and suspended in saline solution for DNA isolation.

\section{PCR for cagA}

Primers used for PCR typing of cagA and for the empty site to document the absence of cag PAI were described previously. ${ }^{89}$ PCR conditions for the cagA primers were 35 cycles of $94^{\circ} \mathrm{C}$ for 30 seconds, $55^{\circ} \mathrm{C}$ for one minute, and $72^{\circ} \mathrm{C}$ for 1.5 minutes, followed by a final extension at $72^{\circ} \mathrm{C}$ for six minutes. For the cag PAI empty site, the PCR conditions were 35 cycles of $94^{\circ} \mathrm{C}$ for one minute, $57^{\circ} \mathrm{C}$ for one minute, and

Abbreviations: FITC, fluorescein isothiocyanate; HRP, horseradish peroxidase; PAl, pathogenicity island; PCR, polymerase chain reaction 


\begin{tabular}{|c|c|c|c|c|c|}
\hline \multirow[b]{2}{*}{ Patient } & \multirow[b]{2}{*}{ Disease } & \multirow[b]{2}{*}{ Site } & \multirow[b]{2}{*}{ PCR $\operatorname{cag} A^{*}$} & \multicolumn{2}{|c|}{ In situ hybridisation } \\
\hline & & & & $\overline{\operatorname{cog} A(+)}$ & $\operatorname{cag} \mathrm{A}(-)$ \\
\hline \multirow[t]{4}{*}{249} & DU & Antrum & + & + & - \\
\hline & & Corpus & + & ND & ND \\
\hline & & Fundus & + & + & - \\
\hline & & Incisura & + & + & - \\
\hline \multirow[t]{4}{*}{251} & DU & Antrum & - & - & + \\
\hline & & Corpus & - & - & + \\
\hline & & Fundus & - & - & + \\
\hline & & Incisura & - & - & + \\
\hline \multirow[t]{4}{*}{252} & GU & Antrum & - & + & + \\
\hline & & Corpus & - & - & + \\
\hline & & Fundus & - & - & + \\
\hline & & Incisura & - & - & + \\
\hline \multirow[t]{4}{*}{254} & NUD & Antrum & - & - & + \\
\hline & & Corpus & - & - & + \\
\hline & & Fundus & - & - & + \\
\hline & & Incisura & - & - & + \\
\hline \multirow[t]{4}{*}{256} & DU & Antrum & + & + & - \\
\hline & & Corpus & + & + & - \\
\hline & & Fundus & + & + & - \\
\hline & & Incisura & + & + & - \\
\hline \multirow[t]{4}{*}{259} & DU & Antrum & + & + & + \\
\hline & & Corpus & $+1-$ & + & + \\
\hline & & Fundus & $+1-$ & + & + \\
\hline & & Incisura & $+1-$ & + & + \\
\hline \multirow[t]{4}{*}{261} & GU & Antrum & + & + & - \\
\hline & & Corpus & + & + & - \\
\hline & & Fundus & + & + & - \\
\hline & & Incisura & + & ND & ND \\
\hline
\end{tabular}

$72^{\circ} \mathrm{C}$ for one minute, followed by a final extension at $72{ }^{\circ} \mathrm{C}$ for six minutes. Amplified products were analysed in $2 \%$ agarose gels.

\section{DNA probes for in situ hybridisation}

For the detection of all $H$ pylori strains a 303 bp oligonucleotide specific for an antigen common to all $H$ pylori strains ${ }^{10}$ was used as a probe (Ag-C probe). For the detection of cagA(+) strains a 349 bp oligonucleotide specific for cag ${ }^{9}$ was used as a probe. The probes were labelled with biotin and were synthesised by Maxim Biotec Inc (San Francisco, California, USA).

\section{Bacteria}

Helicobacter pylori 60190 (ATCC 49503) genotype cagA(+) and $H$ pylori Tx30a (ATCC 51932) genotype cagA(-) were used for evaluation of the probe specificity. Strains were cultured and suspended in saline solution; mixtures of different proportions of each strain were prepared and spotted on to glass slides and immediately fixed in acetone.

\section{In situ hybridisation using bacteria fixed on glass slides}

Slides were incubated with proteinase $\mathrm{K}(20 \mu \mathrm{g} / \mathrm{ml})$ for one minute, washed, and the cagA probe $(4 \mu \mathrm{g} / \mu \mathrm{l})$ was added; for DNA denaturation, slides were incubated for five minutes at $95^{\circ} \mathrm{C}$, and at $4^{\circ} \mathrm{C}$ for 10 minutes. Hybridisation was carried out at $37^{\circ} \mathrm{C}$ for two hours in a humid chamber. Stringent washing was carried out and the biotinylated probes were detected with streptavidin-horseradish peroxidase (HRP)
(NEN Inc, Boston, Massachusetts, USA), followed by Cy3tyramide amplification reagent ${ }^{11}$ (NEN Inc) for 15 minutes at $37^{\circ} \mathrm{C}$. Slides were washed and the $\mathrm{Ag}-\mathrm{C}$ probe $(4 \mu \mathrm{g} / \mu \mathrm{l})$ was added. Denaturation, hybridisation, and stringent washing were done as described for the cagA probe. The second probe was detected with streptavidin-HRP, followed by the fluorescein isothiocyanate (FITC)-tyramide amplification reagent for 15 minutes at $37^{\circ} \mathrm{C}$. Slides were analysed with an epifluorescence or confocal microscope (Carl Zeiss, Jena, Germany).

\section{In situ hybridisation in gastric biopsies}

Sections ( $4 \mu \mathrm{m}$ thick) of each biopsy were mounted on charged slides. Sections were dewaxed, dehydrated, and washed. Slides were placed in Declere (Cell Marque Corp, Austin, Texas, USA) for 15 minutes, washed, and treated with proteinase $\mathrm{K}(25 \mu \mathrm{g} / \mathrm{ml})$ for one minute. Endogenous peroxidase was blocked using $3 \% \mathrm{H}_{2} \mathrm{O}_{2}$. To block biotin, sections were incubated with avidin for 15 minutes, whereas to block avidin they were incubated with biotin for 15 minutes. Sections were covered with $10 \mu \mathrm{l}$ of the cagA probe $(4 \mu \mathrm{g} / \mu \mathrm{l})$. For DNA denaturation, sections were incubated at $95^{\circ} \mathrm{C}$ for five minutes, and at $4^{\circ} \mathrm{C}$ for 10 minutes. Slides were then hybridised overnight at $37^{\circ} \mathrm{C}$ in a humid chamber and washed with HWb (Research Genetics Inc, Huntsville, Alabama, USA) at $60^{\circ} \mathrm{C}$ for 10 minutes. Sections were incubated in protein blocking buffer (Bio SB Inc, Santa Barbara, California, USA) for 30 minutes, and incubated with streptavidin-HRP for 30 minutes. After washing, slides were incubated with Cy3-tyramide for 15 minutes at $37^{\circ} \mathrm{C}$ and 

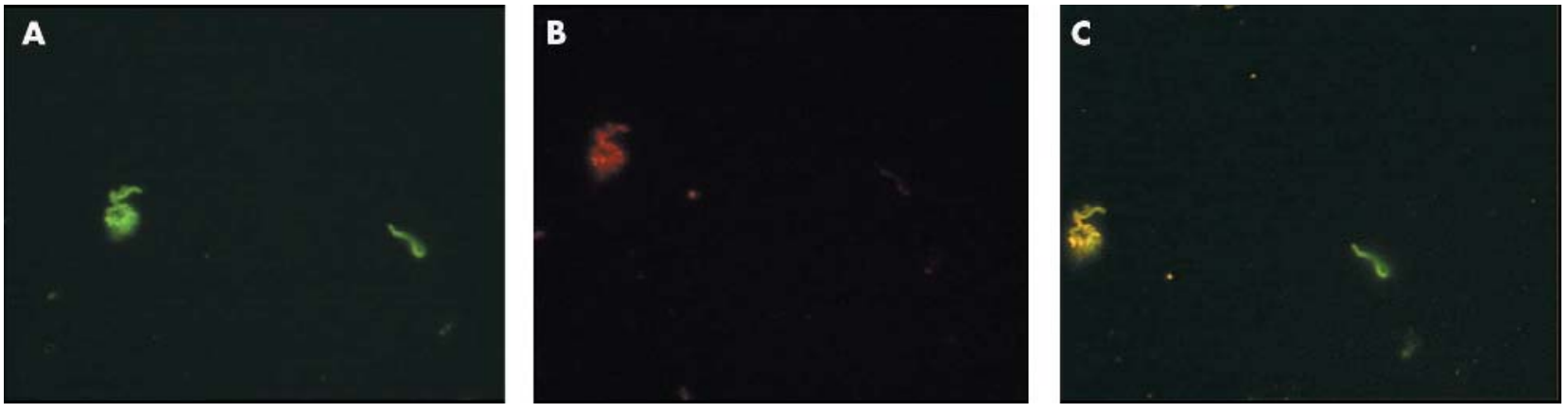

Figure 1 In situ hybridisation for the detection of $\operatorname{cagA}(+)$ and $\operatorname{cagA}(-)$ strains in a mixture of Helicobacter pylori ATCC 49503 (cagA(+)) and Tx30a (cagA (-)) strains fixed on glass slides. The DNA probe for the common antigen was developed with fluorescein isothiocyanate (green) and the probe for cagA was developed with Cy3 (red). (A) green filter; (B) red filter; and (C) triple filter, yellow areas indicate overlapping of the green common antigen and the red cagA, thereby demonstrating the presence of $\operatorname{cag} \mathrm{A}(+)$ strains.

washed. Slides were incubated with $0.1 \%$ saponin for five minutes and washed. The second biotinylated probe for $H$ pylori detection (Ag-C probe) was applied $(4 \mu \mathrm{g} / \mu \mathrm{l})$; hybridisation steps were the same as those for the cagA probe. For detection, FITC-tyramide was applied and developed using similar conditions as for Cy3-tyramide. After washing, slides were counterstained with DAPI and covered with vectashield. The slides were observed with an epifluorescence and a confocal microscope (Carl Zeiss).

\section{RESULTS}

\section{PCR for cagA in single colonies}

In total, $224 \mathrm{H}$ pylori strains were isolated from the four regions of the stomach of the seven patients studied (table 1 ). All strains tested from three patients $(249,256$, and 261) were positive for cagA by PCR. All strains from three patients (251, 252, and 254) were negative for cagA. In patient 259, strains isolated from the antrum were all $\operatorname{cagA}(+)$, whereas strains isolated from the corpus, fundus, and incisura were a mixture of both $\operatorname{cagA}(+)$ and $\operatorname{cag} \mathrm{A}(-)$ strains (table 1 ). In all cag $\mathrm{A}(-)$ strains the absence of the cag PAI was confirmed by amplification of the "empty site" with specific primers.

\section{In situ hybridisation in bacteria fixed on slides}

The performance of the probes specific for the common antigen and for cagA was tested with $H$ pylori 60190 strain $(\operatorname{cagA}(+))$ and strain Tx30a $(\operatorname{cagA}(-))$. Suspensions with different proportions of each strain were fixed and tested. The probes were able to differentiate between $\operatorname{cagA}(-)$ and $\operatorname{cagA}(+)$ strains (fig 1).

\section{In situ hybridisation in gastric biopsies}

No $H$ pylori bacteria were seen in the biopsies of the two patients without $H$ pylori infection. To document the specificity of the staining, bacteria in biopsies from patients colonised with either the $\operatorname{cagA}(+)$ or $\operatorname{cagA}(-)$ strains were scanned and the intensity of the FITC and Cy3 fluorescence was measured (fig 2). Patient 58 was colonised with both $\operatorname{cag} \mathrm{A}(-)$ and $\operatorname{cagA}(+)$ strains and the scanning of a bacterium revealed green with the triple filter, confirming the exclusive presence of FITC fluorescence (fig 2A); patient 67 was colonised with $\operatorname{cag} \mathrm{A}(+)$ strains and the scanning of bacteria with the triple filter demonstrated the presence of both FITC and Cy3 fluorescence (fig 2B).

Table 1 presents the correlation between the cagA PCR results in the single isolates and the in situ hybridisation tests
A
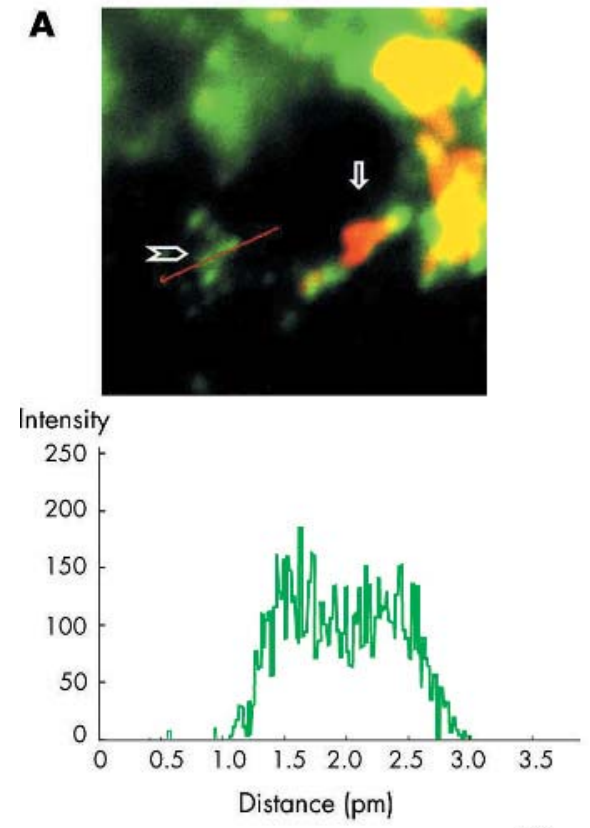

B

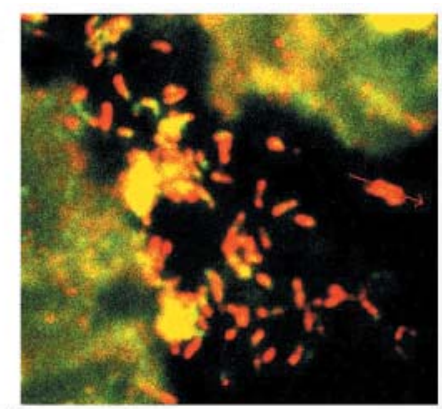

Intensity

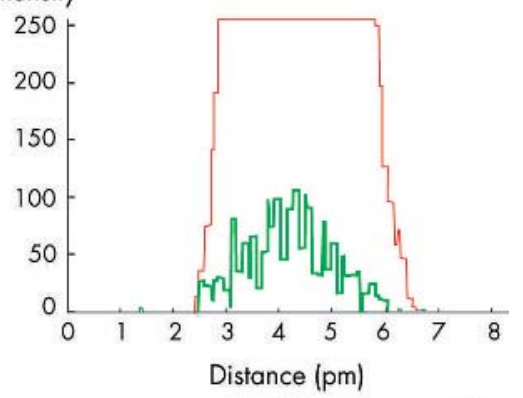

Figure 2 In situ hybridisation for the detection of Helicobacter pylori cagA(+) and $\operatorname{cag} \mathrm{A}(-)$ strains in gastric biopsies of patients colonised with $\mathrm{H}$ pylori. The DNA probe for the common antigen was developed with fluorescein isothiocyanate (FITC; green) and the probe for cagA was developed with Cy3 (red). (A) The gastric biopsy of a patient colonised with both $\operatorname{cagA}(+)$ and $\operatorname{cag} \mathrm{A}(-)$ strains; $\operatorname{a} \operatorname{cag} \mathrm{A}(-)$ bacterium was scanned to show the presence of FITC and the absence of Cy3 fluorescence; the arrowhead points to $\operatorname{cag} \mathrm{A}(-)$ and the arrow to $\operatorname{cag} \mathrm{A}(+)$ bacteria. (B) The gastric biopsy of a patient colonised exclusively with $\operatorname{cag} \mathrm{A}(+)$ strains; a bacterium was scanned to show the presence of both FITC and Cy3 fluorescence. 

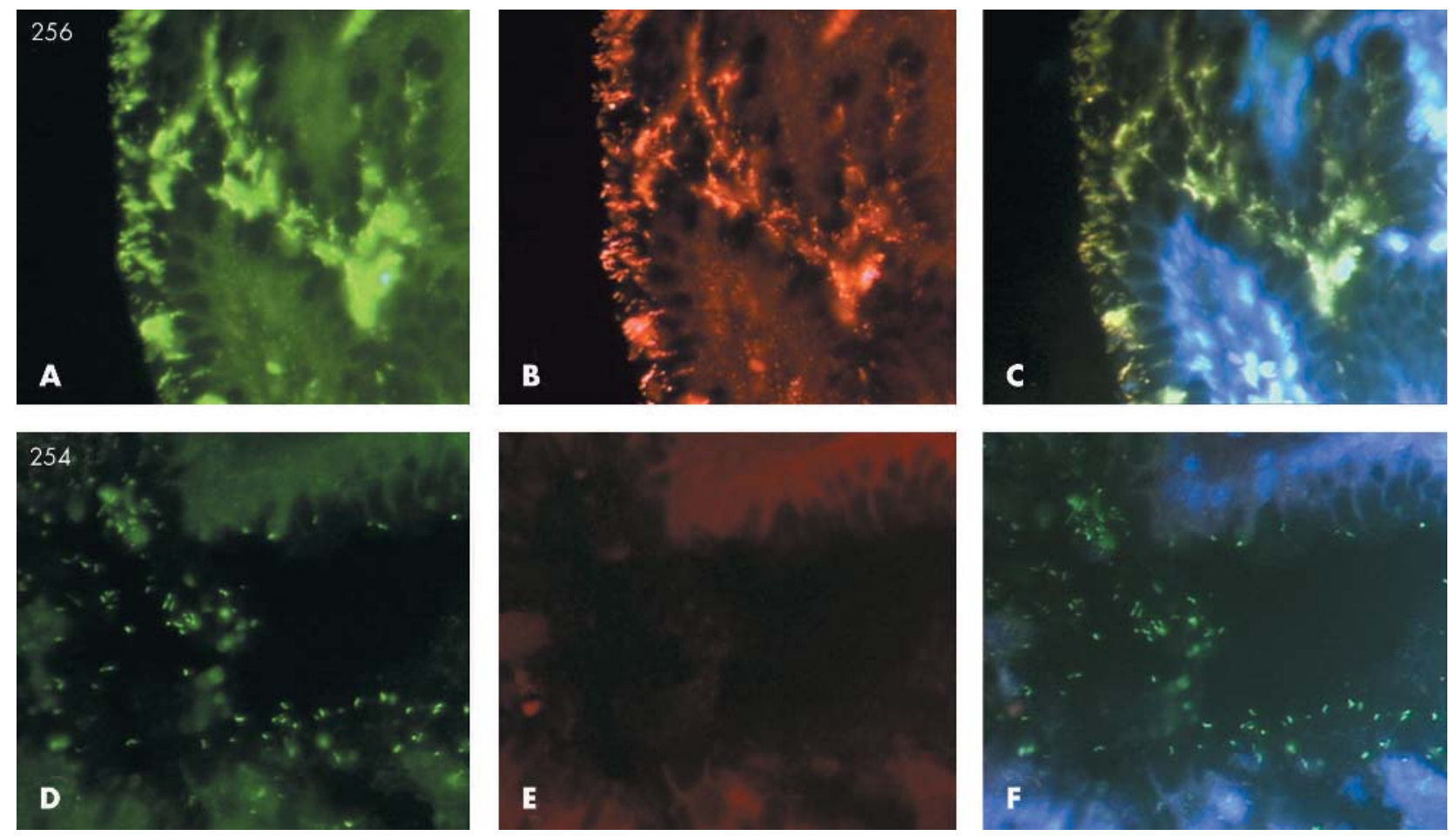

Figure 3 In situ hybridisation for the detection of Helicobacter pylori $\operatorname{cag} \mathrm{A}(+)$ and $\operatorname{cag} \mathrm{A}(-)$ strains in gastric biopsies of patients colonised with $H$ pylori. The DNA probe for the common antigen was developed with fluorescein isothiocyanate (FITC; green) and the probe for cagA was developed with Cy3 (red). (A, D) Green filter; (B, E) red filter; and (C, F) triple filter, the yellow areas indicate overlapping of the green common antigen and the red cagA, thereby demonstrating the presence of $\operatorname{cag} \mathrm{A}(+)$ strains. Patient 256 was colonised with $\operatorname{cagA}(+)$ strains, and colonisation is seen close to the epithelium; patient 254 was colonised with cagA $(-)$ strains, and colonisation is seen mainly in the mucous.

for seven patients studied in four stomach regions. PCR results were confirmed by the in situ hydridisation studies with two exceptions. In patient 252, all single isolates were $\operatorname{cag} \mathrm{A}(-)$ by PCR but some cagA(+) bacteria were identified in the antrum by in situ hybridisation. In patient 259 , all single isolates from the antrum were cagA(+) by PCR but in situ hybridisation demonstrated the presence of some cagA(-) bacteria.

Figure 3 shows the results of biopsies from two patients observed with FITC, Cy3, and the triple filter. In patient 256, all the isolates were cagA(+) by PCR, and the bacteria were seen in situ with all three filters (fig $3 \mathrm{~A}-\mathrm{C}$ ), as expected;
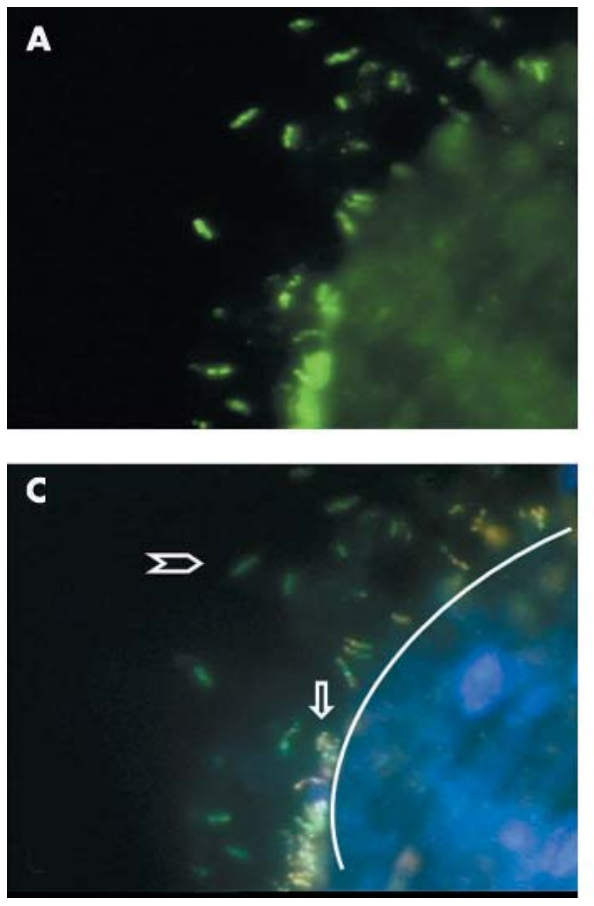
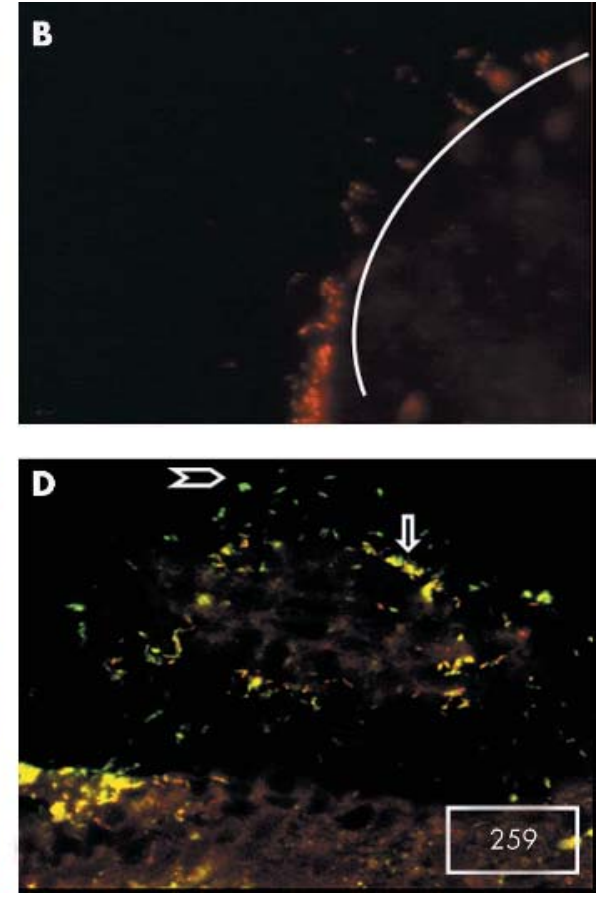

Figure 4 In situ hybridisation for the detection of Helicobacter pylori cagA(+) and $\operatorname{cag} \mathrm{A}(-)$ strains in the gastric biopsy of a patient (259) colonised with both $\operatorname{cagA}(+)$ and $\operatorname{cagA}(-)$ strains. The DNA probe for the common antigen was developed with fluorescein isothiocyanate (FITC; green) and the probe for cagA was developed with Cy3 (red). (A) green filter; (B) red filter; (C) triple filter, yellow areas indicate overlapping of the green common antigen and red cagA, thereby demonstrating the presence of $\operatorname{cag} \mathrm{A}(+)$ strains; and (D) triple filter in confocal microscopy. The arrowhead points to $\operatorname{cag}(-)$ and the arrow to $\operatorname{cag} \mathrm{A}(+)$ bacteria. $\operatorname{cag} \mathrm{A}(-)$ strains are seen colonising mainly the mucous, whereas $\operatorname{cag} \mathrm{A}(+)$ strains are in intimate contact with epithelial cells. 

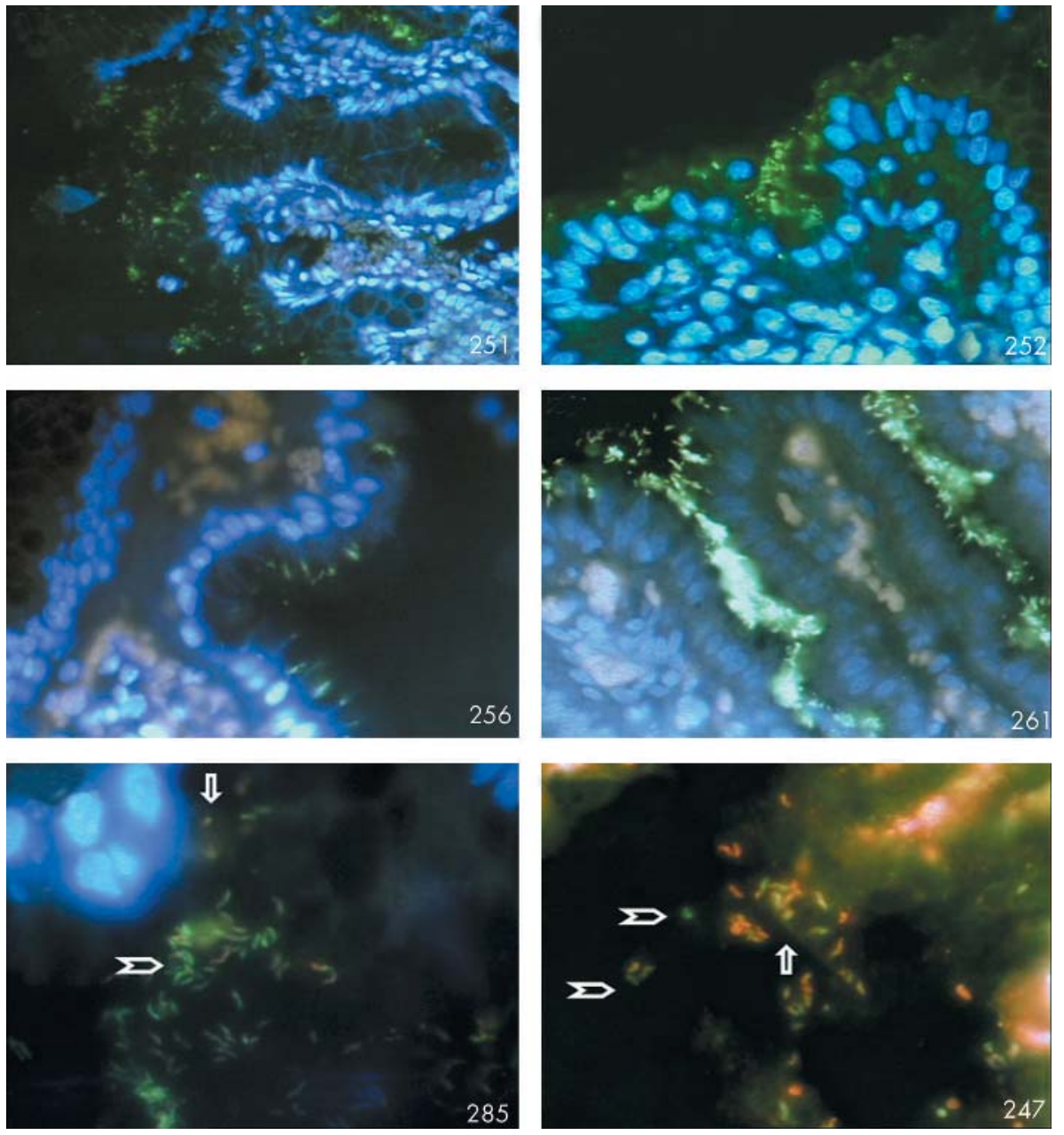

Figure 5 In situ hybridisation for the detection of Helicobacter pylori cagA(+) and $\operatorname{cag} \mathrm{A}(-)$ strains in gastric biopsies of patients colonised with $H$ pylori. The DNA probe for the common antigen was developed with fluorescein isothiocyanate (FITC; green) and the probe for cagA was developed with Cy3 (red). All preparations were observed with the triple filter. Patients 251 and 252 were colonised with $\operatorname{cag} \mathrm{A}(-)$ strains, and colonisation is seen mainly in the mucous or in the proximity of the epithelial cells. Patients 256 and 261 were colonised with $\operatorname{cagA}(+)$ strains, and colonisation is seen in the interepithelial spaces and in intimate contact with the epithelium. Patients 285 and 247 were colonised with both, $\operatorname{cag} \mathrm{A}(-)$ and $\operatorname{cag} \mathrm{A}(+)$ strains. The arrowheads point to $\operatorname{cag} \mathrm{A}(-)$ and the arrows to $\operatorname{cag} \mathrm{A}(+)$ bacteria; in patient 285 some cagA(+) bacteria are seen in intimate contact with the epithelial cells; whereas in patient 247 a few $\operatorname{cag} \mathrm{A}(-)$ bacteria are seen in the mucous. colonisation was seen in the immediate vicinity of the epithelial cells. In patient 254, where all isolates were $\operatorname{cag} \mathrm{A}(-)$ by PCR, bacteria were seen in situ with FITC and the triple filter but not with the Cy3 filter (fig 3D-F), and colonisation was seen mainly in the mucous gel.

Figure 4 shows the results of biopsies from patient 259 in whom isolates were both $\operatorname{cag} \mathrm{A}(+)$ and $\operatorname{cagA}(-)$. All bacteria were stained when the FITC filter was used (fig 4A), whereas with $\mathrm{Cy} 3$ filter (fig 4B) only those bacteria in the immediate vicinity of the epithelial cells were stained $(\operatorname{cagA}(+)$ bacteria); these results were confirmed when the triple filter was used (fig 4C). Confocal microscopy (fig 4D) further documented the differential distribution of $\operatorname{cag} \mathrm{A}(+)$ and $\operatorname{cag} \mathrm{A}(-)$ bacteria.

Figure 5 shows further examples of the interaction of $\operatorname{cagA}(+)$ and $\operatorname{cagA}(-)$ bacteria with the gastric mucosa. In patients 251 and 252, all isolates were shown to be cagA(-) by PCR (table 1); in patient 251, the bacteria colonise mainly the mucous gel, whereas in patient 252 the bacteria are seen in the mucous and near the apical surface of the epithelial cells. In patients 256 and 261 all isolates were cagA(+) by PCR (table 1) and in both cases colonisation is seen in the immediate vicinity of the epithelium, in addition to the intercellular epithelial spaces. Two additional cases (285 and 247) with a mixed infection $(\operatorname{cag} \mathrm{A}(+)$ and $\operatorname{cag} \mathrm{A}(-))$ are presented. In patient 285 colonisation with $\operatorname{cagA}(-)$ bacteria in the mucous gel predominates, although some cagA(+) bacteria can be seen in close contact with the epithelial cells; in patient 247, $\operatorname{cagA}(+)$ bacteria predominate and the few $\operatorname{cag} \mathrm{A}(-)$ bacteria are seen in the mucous gel. Figure 6 shows the pattern of colonisation of some of the cagA(+) bacteria in patient 285, and colonisation of intercellular epithelial spaces is seen.

\section{DISCUSSION}

The presence of the cagA gene is a useful marker for the cag PAI, and gastric colonisation with $\operatorname{cagA}(+)$ strains has been documented by PCR in either isolated bacteria or DNA extracted from biopsies. ${ }^{67}$ However, this approach does not provide information on the in vivo localisation of either $\operatorname{cag} \mathrm{A}(+)$ or $\operatorname{cagA}(-) H$ pylori strains. The possibility of in situ localisation of $\operatorname{cag} \mathrm{A}(+)$ or $(-)$ strains is important in the light of evidence that patients may be colonised with both cagA $(+)$ and $(-)$ strains. ${ }^{12}{ }^{13}$ In our study, we report a technique that allows the in situ detection and differentiation of both $\operatorname{cag} \mathrm{A}(+)$ and $(-)$ strains in gastric biopsies of patients infected with $H$ pylori. Results of in situ hybridisation were confirmed with PCR in multiple isolates from biopsies, with two exceptions, namely: (1) case 252, where PCR showed that all the isolates from the antrum were $\operatorname{cagA}(-)$, whereas in situ hybridisation documented colonisation with both $\operatorname{cag} \mathrm{A}(+)$ and (-) strains; and (2) case 259, where all the isolates from the antrum were $\operatorname{cagA}(+)$, whereas in situ hybridisation showed the presence of both cagA $(+)$ and $(-)$ strains. These results suggest that the sensitivity of culture, even after testing multiple isolates, to identify strains with different genotypes is lower than that of in situ hybridisation.

In our study, initial attempts at in situ hybridisation of both the $\operatorname{cag} \mathrm{A}(+)$ and $(-)$ strains using probes directly 

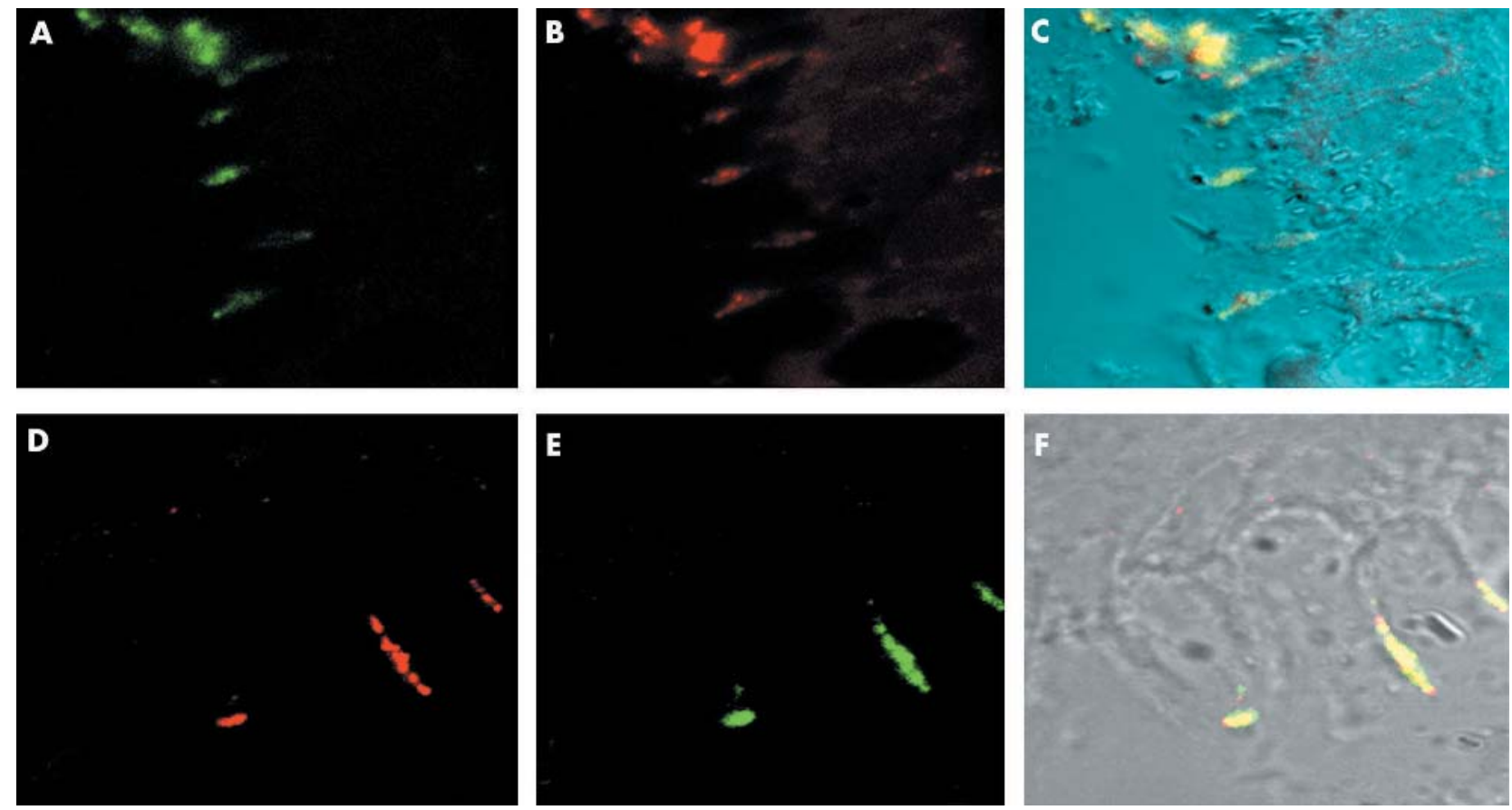

Figure 6 In situ hybridisation for the detection of Helicobacter pylori cagA $(+)$ and $\operatorname{cag} \mathrm{A}(-)$ strains in gastric biopsies of patient 285. The DNA probe for the common antigen was developed with fluorescein isothiocyanate (FITC; green) and the probe for cagA was developed with Cy3 (red). (A, D) green filter; (B, E) red filter; (C, F) triple filter, the yellow areas indicate the overlapping of the green common antigen and the red cagA, thereby demonstrating the presence of $\operatorname{cagA}(+)$ strains. Two different regions of the epithelium are presented to show colonisation in the intercellular epithelial space.

labelled with fluorochromes gave unsatisfactory results. The technique was greatly improved when we used the tyramide method to amplify the signal. ${ }^{14}$ This technique has been shown to increase the sensitivity for in situ detection of antigens and DNA markers in different systems. ${ }^{15}$

"Our results suggest that the sensitivity of culture, even after testing multiple isolates, to identify strains with different genotypes is lower than that of in situ hybridisation"

A recent study reported the ability of cag PAI (+) strains to colonise the intercellular space of epithelial cells in culture and to disrupt the organisation of tight junctions. ${ }^{16}$ In our

\section{Take home messages}

- We developed an in situ hydridisation method to localise $\operatorname{cagA}(+)$ and $(-)$ strains of Helicobacter pylori in the stomach of infected individuals

- In cases of colonisation with $\operatorname{cagA}(-)$ strains, infection was seen mostly in the mucous gel or in areas near the apical surface of epithelial cells, whereas in cases of colonisation with $\operatorname{cag} \mathrm{A}(+)$ strains, the bacteria were seen in more intimate contact with the epithelium, in the immediate vicinity of the epithelial cells or in the intercellular epithelial spaces

- These results confirm the observations made in tissue culture with $\operatorname{cagA}(+)$ strains

- This method might help elucidate the role of cagA in the development of gastroduodenal diseases associated with $\mathrm{H}$ pylori infection study, we found that in cases of colonisation with $\operatorname{cag} \mathrm{A}(-)$ strains, infection is mostly seen in the mucous gel or in areas near the apical surface of epithelial cells, whereas in cases of colonisation with cagA $(+)$ strains, the bacteria are seen in more intimate contact with the epithelium, in the immediate vicinity of the epithelial cells or in the intercellular epithelial spaces. In fact, the study of cases with infection of both $\operatorname{cag} \mathrm{A}(+)$ and $(-)$ strains allowed us to document further the areas of colonisation by these two strains. We confirm the observations made in tissue cultures with cagA(+) strains, ${ }^{16}$ and suggest that colonisation by cagA $(-)$ strains is restricted to the mucous gel or the apical surface of epithelial cells. Although this pattern of colonisation by $\operatorname{cagA}(+)$ and $(-)$ strains has been suggested previously, ${ }^{17}$ our results document for the first time that this pattern of colonisation occurs in vivo. We acknowledge the possibility that the patterns of colonisation seen here might not result exclusively from the presence of the cag PAI, and that other genes, such as babA, a gene encoding an adhesin with affinity for the Lewis $b$ antigen, might also play a role. ${ }^{18}$

The method described here could help elucidate the role of cagA in the development of gastroduodenal diseases associated with $H$ pylori infection. Our results document a difference between the in vivo interaction of $H$ pylori $\operatorname{cag} \mathrm{A}(+)$ or $\operatorname{cagA}(-)$ strains and the gastric mucosa.

\section{ACKNOWLEDGMENTS}

This work was supported by CONACYT (grant 34565-M), Mexico; and by the Coordinacion de Investigacion en Salud, IMSS, Mexico. We thank A Eras (Bio SB Inc) and Dr L Santos (Cinvestan, Mexico) for technical advice.

\section{Authors' affiliations}

M Camorlinga-Ponce, C Romo, G González-Valencia, O Muñoz,

J Torres, Unidad de Investigación en Enfermedades Infecciosas, Hospital de Pediatría, Instituto Mexicano del Seguro Social, Mexico 


\section{REFERENCES}

1 Peek RM, Blaser MJ. Helicobacter pylori and gastrointestinal tract adenocarcinoma. Nat Rev Cancer 2002;2:28-37.

2 Atherton JC, Peek RM, Tham KT, et al. Clinical and pathologic importance of heterogeneity in vacA, the vacuolating cytotoxin gene of Helicobacter pylori. Gastroenterology 1997;1 12:92-9.

3 Ching CK, Wong BCY, Kwok E, et al. Prevalence of CagA-bearing Helicobacter pylori strains detected by the anti-CagA assay in patients with peptic ulcer disease and in controls. Am J Gastroenterol 1996;91:949-53.

4 Akopiants NS, Clifton SW, Kersulyte D, et al. Analyses of the cag pathogenicity island of Helicobacter pylori. Mol Microbiol 1998;28:37-53.

5 Crabtree JE, Covacci A, Farmery SM, et al. Helicobacter pylori induced interleukin-8 expression in gastric epithelial cells is associated with CagA positive phenotype. J Clin Pathol 1995;48:41-5.

6 Figueiredo C, Quint W, Nouhan N, et al. Assessment of Helicobacter pylor vacA and cagA genotypes and host serological response. J Clin Microbiol 2001;39:1339-44.

7 van Doorn L, Figueiredo C, Rossau R, et al. Typing of Helicobacter pylori vacA gene and detection of cagA gene by PCR and reverse hybridization. J Clin Microbiol 1998:36:1271-6.

8 Censini S, Lange C, Xiang Z, et al. cag A pathogenicity island of Helicobacter pylori encodes type I-specific and disease-associated virulence factors. Proc Natl Acad Sci U S A 1996;93:14648-53.

9 Tummuru MK, Cover T, Blaser MJ. Cloning and expression of a highmolecular-mass major antigen of Helicobacter pylori: evidence of linkage to cytotoxin production. Infect Immun 1993;61:1799-809.
10 O'Toole PW, Logan SM, Kostrzynska M, et al. Isolation and biochemical and molecular analyses of a species-specific protein antigen from the gastric pathogen Helicobacter pylori. J Bacterio 1991;173:505-13.

11 Speel E, Hopman A, Komminoth P. Amplification methods to increase the sensitivity of in situ hybridization: play card(s). J Histochem Cytochem 1999;47:281-8.

12 Gonzalez-Valencia G, Atherton JC, Muñoz O, et al. Helicobacter pylori vacA and $\mathrm{CagA}$ genotypes in Mexican adults and children. $J$ Infect Dis 2000;182:1450-4.

13 Kuipers EJ, Israel DA, Kusters JG, et al. Quasispecies development of Helicobacter pylori observed in paired isolates obtained years apart from the same host. J Infect Dis 2000;181:273-82.

14 Kerstens HM, Poddighe PJ, Hanselaar AG. A novel in situ hybridization signal amplification method based on the deposition of biotinylated tyramide. J Histochem Cytochem 1995;43:347-57.

15 Rob PM, Zijlmans MA, Wiegant J, et al. Flurochrome-labeled tyramides: use in immunocytochemistry and fluorescence in situ hybridization. J Histochem Cytochem 1997:45:375-82.

16 Amieva MR, Vogelmann R, Covacci A, et al. Disruption of the epithelial apical-junctional complex by Helicobacter pylori CagA. Science 2003:300:1430-4.

17 Blaser MJ, Berg DE. Helicobacter pylori genetic diversity and risk of human disease. J Clin Invest 2001;107:767-73.

18 Ilver D, Arnqvist A, Ogren J, et al. Helicobacter pylori adhesin binding fucosylated histo-blood group antigens revealed by retagging. Science 1998;279:373-7. 